\title{
Investigating the Synergies of Sustainability and BIM through Collaborative Project-based Learning
}

\section{Dr. Wei Wu, California State University, Fresno}

Wei Wu, PhD, LEED AP, CM-BIM, A.M.ASCE, is an Assistant Professor of the Construction Management Program in Lyles College of Engineering at California State University, Fresno. He received the Bachelor of Engineering in Civil Engineering with a focus on Built Environment from Hunan University in China, the Master of Science in Environmental Change and Management at University of Oxford in the UK, and the Doctor of Philosophy in Design, Construction and Planning at University of Florida. He is an associate member of ASCE, a member of DBIA, Green Globes, and National Institute of Building Science. He is also a board member of USGBC Central California Chapter, and Senior Fellow of the Environmental Leadership Program (ELP).

\section{Dr. Yupeng Luo, California State University, Fresno}

Dr. Yupeng (Vivien) Luo is an Associate Professor in the Construction Management Program at California State University, Fresno. She holds an M.S. in Civil Engineering from the University of Pittsburgh and a Ph.D. in Architectural Engineering from the Pennsylvania State University. Her research interests include sustainable building solutions, building performance measurement, decision-making \& optimization, service-learning and community engagement. Dr. Luo is a LEED AP BD+C and a CM-BIM holder. 


\title{
Investigating the Synergies of Sustainability and Building Information Modeling through Collaborative Project-based Learning
}

\begin{abstract}
The construction industry is undergoing fundamental transformation due to economic, social, and environmental development. Highlights of emerging trends include the prevalence of green building practices and a wide adoption of new information technology (IT) such as building information modeling (BIM). The paradigm shift demands a higher level of competencies in sustainability and BIM, which generates a profound impact on college education in design and construction related fields. This study explores the effective use of collaborative project-based learning to enhance students' understanding of sustainability and BIM implementation in facilitating green building design.

In the fall of 2014, the faculty in the Construction Management (CM) program at California State University, Fresno (Fresno State) closely examined two existing courses (CM-132 and CM-177) through a joint course project. CM-132 encapsulates BIM principles, modeling skills, and implementation of BIM to facilitate high performance building design and construction. CM-177 introduces green building design guidelines, rating systems, and common practices. Students from the two classes made up project teams to co-develop Leadership in Energy and Environmental Design (LEED) strategies and conduct performance analysis that is essential for accomplishing LEED certification with BIM for a project on campus. The collaborative project-based learning is responsive to the real world scenario where green building design and BIM are often implemented through an integrative process. Both direct and indirect measures were used to assess the effectiveness of the proposed collaborative project-based pedagogy on selected core student learning outcomes (SLOs). Rubrics were developed for each measure. This paper discusses the findings, lessons learned from this study, and provides insights into future improvements.
\end{abstract}




\section{Introduction}

The construction industry is undergoing fundamental transformation due to economic, social, and environmental development. Consequently, construction engineering education is also facing unprecedented challenges from transformative industry trends such as green building and building information modeling (BIM). Enormous efforts have been made in college curricula for adaptation to the rapidly changing industry environment and cultivation of the next-generation workforce with desired competencies in sustainability and BIM. While most pedagogical innovations have addressed both topics, they are typically taught as separate subjects, providing that the synergistic convergence of sustainability and BIM has been embraced by both professional and educational communities ${ }^{[1,2]}$. This study investigated an integrative strategy to formulate a joint course project with concurrent focus on sustainable design and BIM implementation using two upper division elective courses in an undergraduate construction management $(\mathrm{CM})$ program.

This study was motivated by the dual pressure from program assessment requirements and regional industry needs. Recent American Council for Construction Education (ACCE) reaccreditation review of the CM program revealed severe weaknesses of students in graphical communication, construction modeling and visualization. Meanwhile, the Central Valley has seen a slow but steady rising trend in green building and adoption of BIM. Industry recruiters have clearly indicated strong market demands for new graduates with knowledge and skills in sustainability and BIM. It is a high priority of the program to sustain a nimble and practical curriculum that is responsive to industry trends and able to cultivate the desired talent for local employers. Hence, in this study the course redesign was purposely aligned with the program student learning outcomes (SLOs) and emerging industry needs. The goal was to develop student competencies with effective means and better prepare them for their future career roles in an interdisciplinary project-based industry.

\section{Background}

The synergistic convergence of sustainability and BIM has been embraced by both professional and educational communities. There is abundant documented literature suggesting the strong interests among industry players and research scholars in how BIM facilitates accomplishing more sustainable project outcomes. For instance, in the United States, the General Service Administration (GSA) is leading the efforts to leverage BIM for high performance buildings by establishing the national 3D-4D BIM program and publishing the BIM guide series ${ }^{[3]}$. The U.S. Department of Energy (DOE) and the office of energy efficiency and renewable energy (EERE) have also instituted efforts to utilize advanced modeling and simulation technology via broad stakeholder involvement for significant energy savings in capital projects. The building technologies program, the Commercial Building Initiative (CBI), and the commercial reference building models for national building stock are highlights among these efforts ${ }^{[4]}$. There is also a good diversity of scholarly research on BIM and green building design and construction. With LEED being a globally recognized green building rating system, BIM implementation in LEED design, credit analysis, and documentation have caught great attention in the research community. Quite a few researchers have addressed BIM/LEED synergies. For instance, Biswas et al. ${ }^{[5]}$ and $\mathrm{Wu}$ and Issa ${ }^{[6]}$ proposed system level integration of BIM and LEED; Barnes and 
Castro-Lacouture ${ }^{[7]}$ and Bank et al. ${ }^{[8]}$ demonstrated the possibilities of using BIM as a sustainable design decision-making tool, and relying on BIM-based information for certain LEED points calculation. In addition, O'Keeffe et al. ${ }^{[9]}$ Azhar et al., ${ }^{[10]}$, and Wu and Issa ${ }^{[11]}$ looked at how BIM could facilitate the LEED certification process with design analysis optimization, information management, documentation generation, and certification review.

From the pedagogy perspective, various models have been tested in curriculum redesign to enhance the integration of BIM and sustainability contents ${ }^{[12]}$. It has been revealed through these academic initiatives that transformative trends such as BIM and green building call for strong communication and teamwork skills, capacity to work efficiently within co-located teams and abilities to apply fundamental engineering, management and computer skills in real world scenarios ${ }^{[13]}$, yet traditional lecture-based pedagogical models are no longer efficient to delivery these goals. An intrinsic drawback of these models resides in the fact that students are treated as passive recipients with linear and fragmented teaching presentations, and deprived of the opportunities for learning the holistic nature and broad vision of the architecture, engineering and construction (AEC) disciplines ${ }^{[14]}$.

In contrast, project-based learning as a proven effective student-centered pedagogical approach ${ }^{[15]}$ has been gaining popularity and holds the promise of cultivating the desired competency for future workforce with breadth and depth ${ }^{[16]}$. Project-based learning allows students to build knowledge ${ }^{[17]}$, develop critical thinking, creativity ${ }^{[18]}$ and a number of soft skills (e.g. leadership and communication) ${ }^{[19]}$. Aside from student learning process, project-based learning also redefines and transforms the role of the instructor. Instead of being the point of authority and source of solution, the instructor in project-based learning works as a mentor and/or an expert consultant who helps students formulate their own strategies towards the accomplishment of project goals with open-ended, heuristic suggestions while avoid offering the "answer key". The underlying purpose is to instill metacognition and self-monitoring skills of students in facing, analyzing and resolving problems and complexities in realistic project scenarios ${ }^{[14]}$.

\section{Research objectives and methodology}

The proposed study aimed to investigate the use of project-based learning to cultivate essential knowledge and skills in BIM and sustainability through a collaborative joint course project. This effort was also aligned with program assessment objectives to enhance SLOs in the following areas:

- SLO 1: Communication. Effective communication in graphical, oral, and written forms common in the construction industry.

- SLO 3: Teamwork and Team Relations. Work closely with other team members that are internal and external to the construction project team.

- SLO 4: Problem Solving and Critical Thinking. Solve diverse problems in the design and construction of the project.

- SLO 11: Sustainability. Become literate in sustainability and apply the principles to the design and construction process.

Due to the fact that BIM has been a new element of the curriculum, SLO 1 and SLO 4 were used as the tentative placeholders for assessment activities pertaining to BIM competencies. More 
comprehensive metrics will be developed as the $\mathrm{CM}$ program accumulates experience and student learning data in BIM. For this study, the assessment of knowledge, modeling skills and analysis abilities of using BIM in the sustainability domain were addressed by developing grading rubrics for specific project deliverables.

The joint course project was coordinated by instructors of two upper division electives enrolled majorly by senior students with a few juniors, including CM-132: Advanced Architectural Design and CM-177: Sustainable Construction, with assistance from the industry partner who is the general contractor of the selected campus laboratory project. The overarching joint course project goal set for students was to develop strategies, create designs, conduct analyses and prepare documentation in pursuit of LEED certification facilitated by BIM. Project teams were made of 4-5 students from the two classes, with assigned roles and responsibilities including:

- One (1) LEED Consultant: lead the LEED charrettes to develop alternative design strategies aiming at two LEED targets: LEED certified and one higher level LEED certification: silver, gold, or platinum (decided by the team); prepare LEED documentation.

- One (1) BIM Coordinator/Project Manager: establish the BIM execution plan with identified sustainability goals; coordinate team communication; manage team activities;

- One (1) Design Professional: build the conceptual design model; conduct performance modeling based on the design strategies and performance criteria proposed by the LEED consultant.

- One (1) Owner's Representative: provide inputs to other team members from the owner's perspective (more focus on budget and time control) to support their work; assist in design review and project documentation.

- One (1) Project Engineer (optional): provide inputs to other team members from a project engineer's perspective (more focus on constructability) to support their work; assist in project documentation.

Except for the LEED consultants, other team members were encouraged to rotate roles during the process to enhance their learning experience. The overall assessment plan of this study emphasized on the learning progressions and periodical reflections, and included both formative and summative approaches. Considering the lack of previous exposure of students to similar topics, the instructors opted to leverage external educational resources provided by Autodesk, and incorporated the online Building Performance Analysis Certificate (BPAC) program as part of project personnel training requirements. The certificate program embraces broad but fundamental knowledge and skills in building physics, building systems, and information modeling applications that can jumpstart students' understanding of the synergies between sustainability and BIM.

As for LEED resources, students in CM-177 were provided with access to US Green Building Council (USGBC)'s interactive web-based LEED reference guide that offers step-by-step guidance on how to achieve and document each LEED credit for both the current and previous LEED rating systems. In addition, CM-177 students conducted case studies on two recently awarded LEED platinum projects on a nearby university campus after reviewing the complete final LEED submittals. They were expected to learn LEED strategies from the case studies and 
apply them to the joint course project as they saw fit. Table 1 summarizes the corresponding direct/indirect measures planned for assessing the preceding list of program SLOs.

Table 1. Joint course project assessment plan.

\begin{tabular}{|c|c|c|c|c|c|c|c|}
\hline \multirow[t]{2}{*}{ Program SLOs } & \multicolumn{5}{|c|}{ Direct Measures } & \multicolumn{2}{|c|}{$\begin{array}{l}\text { Indirect } \\
\text { Measures }\end{array}$} \\
\hline & $\begin{array}{l}\text { Model \& Desigr } \\
\text { Documentation }\end{array}$ & $\begin{array}{l}\text { Team } \\
\text { Presentation }\end{array}$ & $\begin{array}{l}\text { Team } \\
\text { Final } \\
\text { Report } \\
\end{array}$ & $\begin{array}{l}\text { Team } \\
\text { Google } \\
\text { Site }\end{array}$ & $\begin{array}{l}\text { Autodesk } \\
\text { BPAC }\end{array}$ & $\begin{array}{l}\text { Entry } \\
\text { Survey }\end{array}$ & $\begin{array}{l}\text { Exit } \\
\text { survey }\end{array}$ \\
\hline SLO 1 & $x$ & $\times$ & $x$ & $x$ & & $x$ & $x$ \\
\hline SLO 3 & & $x$ & $x$ & $x$ & & & $x$ \\
\hline SLO 4 & $x$ & $x$ & $x$ & & $x$ & & $x$ \\
\hline SLO 11 & & & $x$ & $x$ & $x$ & $x$ & $x$ \\
\hline
\end{tabular}

\section{Project implementation}

In fall 2014, the joint course project kicked off in late September and completed in December for a total duration of three and a half months. The project was scheduled in phases typically followed in real green BIM project delivery practices, as illustrated in Figure 1. At each phase, there were specific tasks and deliverables to be completed by each team. Students were required to perform LEED strategy analysis via LEED design charrettes, determine the appropriate BIM execution plan, create the design and analysis models, conduct performance simulation, prepare reports on simulation results and LEED documentation, and eventually compile a final report/project manual summarizing all project activities and results.

LEED Strategy

and BIM

Execution Plan
Criteria

Design
Implementation

Documentation

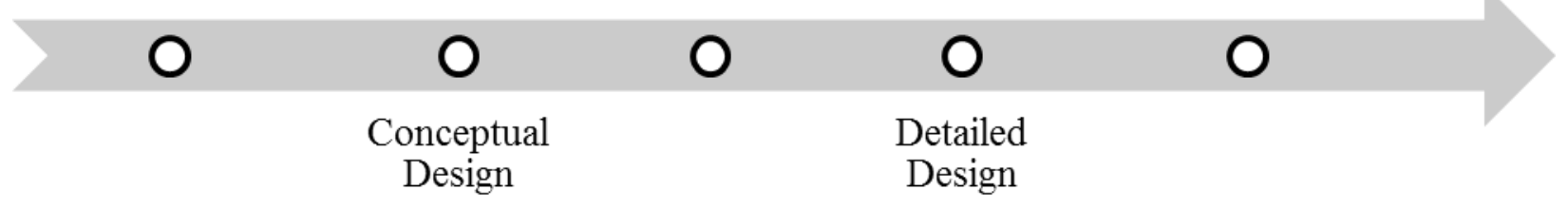

Figure 1. Joint course project delivery process.

Collaboration is the key to optimal results. Teams were expected to meet weekly either face-toface or online to stay on track of their assigned responsibilities. To better facilitate documentation management and communication among team members, each team was required to create and maintain a Google site introducing each individual's roles and presenting weekly updates on their project deliverables. Complete project files were stored on Google drive or Dropbox with links shared on the Google site. In addition, there was a joint course Google site co-managed by the two course instructors. The site served as a hub to share project documentation (e.g. links to original building plans and models were provided), grading rubrics, as well as weekly assignments and/or announcements from both courses. All the team sites were linked to this central site and were only accessible to the instructors. 
A great benefit for those who participated in this joint course project was the exposure to a wide selection of technological tools for various project tasks such as model authoring, performance simulation, documentation management, team communication, to name a few. In order to simulate a real integrative project design process with BIM facilitation and sustainability goals, the tools were carefully selected based on specific project needs and the current industry trends. Table 2 summarizes the technology selection process.

Table 2. Technology selection for the joint course project.

\begin{tabular}{|c|c|c|}
\hline Project activity/task & Recommended technology & Optional technology \\
\hline Site selection/analysis & Google Earth & - \\
\hline Model authoring & Autodesk Revit 2014 & Sketchup \\
\hline Energy simulation & $\begin{array}{l}\text { Autodesk Green Building } \\
\text { Studio }\end{array}$ & Sefaira \\
\hline Water efficiency calculation & $\begin{array}{l}\text { Autodesk Green Building } \\
\text { Studio }\end{array}$ & - \\
\hline Daylighting simulation & $\begin{array}{l}\text { Autodesk Green Building } \\
\text { Studio }\end{array}$ & $\begin{array}{l}\text { Sefaira; Autodesk Daylighting } \\
\text { Analysis plug-in* }\end{array}$ \\
\hline Materials takeoff & Autodesk Revit 2014 & On Screen Takeoff \\
\hline $\begin{array}{l}\text { Design documentation } \\
\text { communication \& management }\end{array}$ & $\begin{array}{l}\text { Google Apps; Dropbox; } \\
\text { PlanGrid }\end{array}$ & Autodesk A360 \\
\hline LEED certification management & Google Apps & $\begin{array}{l}\text { Autodesk Revit Credit Manager } \\
\text { for LEED** }\end{array}$ \\
\hline
\end{tabular}

*,**: Both are Autodesk Labs products.

To facilitate the preparation of project deliverables by student teams, a specification on the project manual contents and formatting was provided (Figure 2). Students were required not only to produce the pertinent artefacts, but also document their reflections for each tasks performed, lessons learned and recommendations for future improvement. This enforced and deliberative reflection process was critical to help them digest and consolidate their learning. Examples of student works are presented in Figure 3, which were taken from a poster session on the student project day exhibition.

(a)

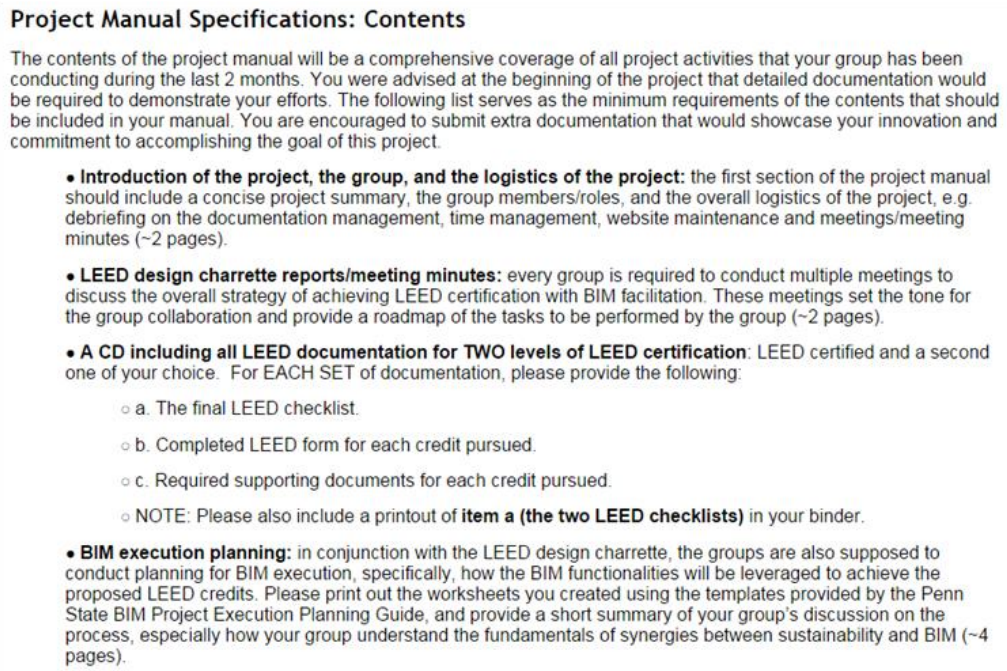


(b) Project Manual Specifications: Formatting Previous program assessment has revealed a major weakness of the CM students to be the lack of communication skills,
including business writing, oral presentation and graphical communication. The expectation for the project manual is thus set as to evaluate the groups' competency in business writing and professional presentation. The following formatting requirements are non-exhaustive and only serve as guidance to prepare the manual.

- Cover sheet \& table of contents: all project manuals should be prepared and produced in a professional manner. A 2-inch 3-ring binder will be provided by the instructor. A cover sheet is required, including the project e group number, group members and submission date. Inside the binder, a table of contents is required to major sections of the manual.

- Signature Page: right after the table of contents, a signature page should be included to officially declare the completion of the joint course project. All members of the group have to sign with date.

- Fonts and spacing: the manual should be prepared using consistent fonts (please choose one from Time New Roman, Arial, Calibri, Cambria, Georgia and Garamond) with appropriate font size (minimum size at 11). The manual should use single spacing.

- Sections and Headings: groups should follow the logical order to include all required project deliverables, and use sections and headings to structure the project manual so the reviewers can easily follow the information you provide. The sections and headings should be consistent with the table of contents

- Tables and Figures: all tables and figures should be titled, with the table title before the table, and the figure title after the figure. The quality of the figures should be satisfactory with sufficient resolution. Please use color printing when necessary.

- References: any materials and information used by but are not the original work of the groups should be cited and listed in the references section to give credits to the original authors. Plagiarism will absolutely not be tolerated

Figure 2. Project manual specifications: (a) contents; and (b) formatting.
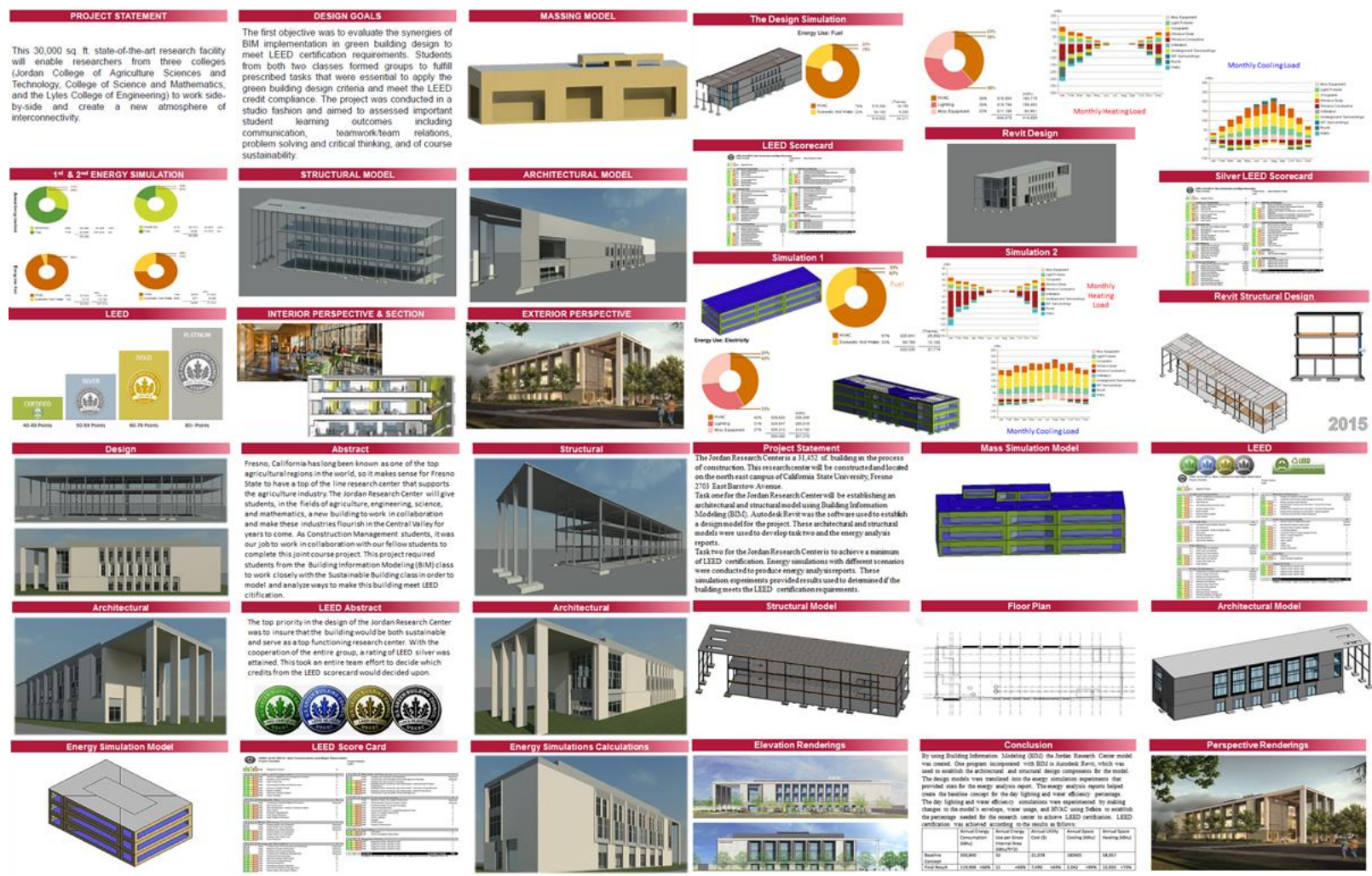

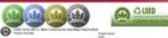
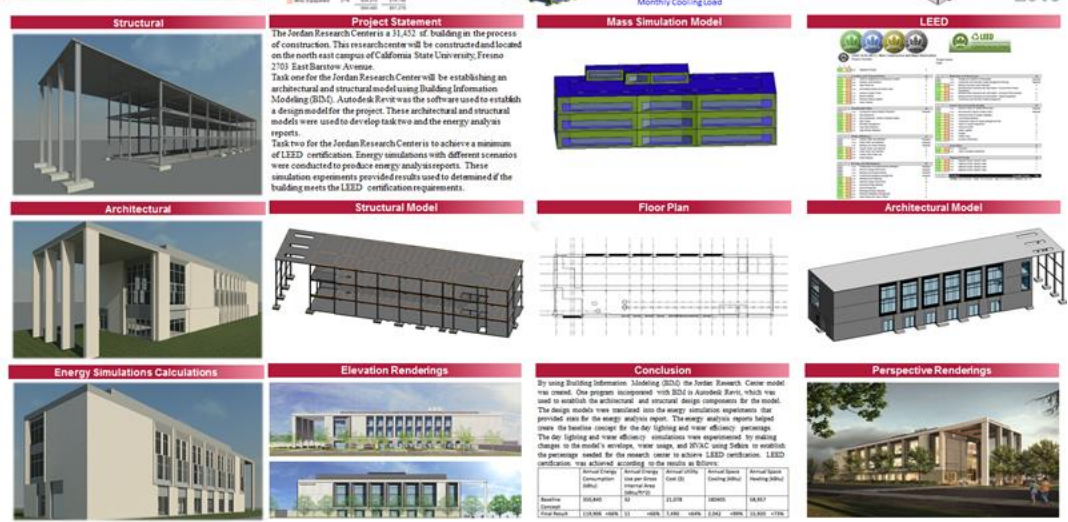

Figure 3. Exhibits of student works of the joint course project.

\section{Assessment results and discussion}

Through the joint course project, instructors collected the assessment data following the assessment plan specified in the preceding Table 1. Each SLO was assessed through multiple measures. For each direct measure, instructors developed certain metrics and grading rubrics to assess relevant student assignments and activities. For instance, Model \& Design Documentation 
is a direct measure utilized to assess SLO 1: Communication and SLO 4: Problem Solving \& Critical Thinking. Relevant student assignments/activities included creating the schematic architectural and structural Revit model, performing massing- and building element-based energy simulations, conducting daylighting analysis, calculating water efficiency and recycled contents, and running design analysis reports, to name a few. Another direct measure, the Autodesk BPAC, provided a comprehensive assessment of students' fundamental knowledge in building physics and high performance design criteria through a series of well-designed, very relevant learning modules. It also evaluated essential problem-solving skills utilizing BIM applications to accomplish sustainable design goals. Figure 4 provides sample grading rubrics used for Team Presentation (a direct measure for SLOs 1, 3, and 4) and Team Final Report (a direct measure for all four SLOs).

\begin{tabular}{|c|c|c|c|c|c|}
\hline \multirow{2}{*}{ Grading Criteria } & 1 & 2 & 3 & 4 & 5 \\
\hline & Poor & Below Expectation & Meet Expectation & Confident & Advanced \\
\hline Physical Appearance & $\begin{array}{l}\text { No attempt made to } \\
\text { improve. Typical street } \\
\text { clothing worn. }\end{array}$ & $\begin{array}{l}\text { Some attempt made } \\
\text { but too casual for } \\
\text { presentation }\end{array}$ & $\begin{array}{l}\text { Dress clean yet not } \\
\text { suitable for } \\
\text { presentation }\end{array}$ & $\begin{array}{l}\text { Dress clean and } \\
\text { suitable but not } \\
\text { business oriented }\end{array}$ & $\begin{array}{l}\text { Business-casual or } \\
\text { better, professional } \\
\text { dressing }\end{array}$ \\
\hline $\begin{array}{l}\text { Presentation } \\
\text { Organization }\end{array}$ & $\begin{array}{l}\text { Presenters are not } \\
\text { prepared and poor } \\
\text { organization of } \\
\text { contents. }\end{array}$ & $\begin{array}{l}\text { Presentation is very } \\
\text { confused and unclear. } \\
\text { No objectives } \\
\text { identified. }\end{array}$ & $\begin{array}{l}\text { Effort required by } \\
\text { listeners to follow the } \\
\text { presentation. } \\
\text { Objectives are } \\
\text { inconsistent. }\end{array}$ & $\begin{array}{l}\text { Presentation is general } \\
\text { clear. }\end{array}$ & $\begin{array}{l}\text { Presentation is clear } \\
\text { and logical. Opening } \\
\text { included clearly stated } \\
\text { objectives. }\end{array}$ \\
\hline Delivery & $\begin{array}{l}\text { Speakers cannot be } \\
\text { heard. Presentation } \\
\text { was too short or long. } \\
\text { Key points not } \\
\text { summarized. }\end{array}$ & $\begin{array}{l}\text { Information is read } \\
\text { from a script of } \\
\text { directly from the } \\
\text { scream. Poor posture } \\
\text { and no eye contact. }\end{array}$ & $\begin{array}{l}\text { An annoying number } \\
\text { of "Ahs and Ums". } \\
\text { Pace is too fast or too } \\
\text { slow. Key points are } \\
\text { touched upon without } \\
\text { adequate articulation. }\end{array}$ & $\begin{array}{l}\text { Reasonable pace and } \\
\text { style. Some rough } \\
\text { spots. Overall easy to } \\
\text { follow and contents are } \\
\text { complete. }\end{array}$ & $\begin{array}{l}\text { Planned conversation } \\
\text { with the audience, } \\
\text { paced for } \\
\text { understanding. } \\
\text { Articulate \& enjoyable } \\
\text { to listen to. Good } \\
\text { layout. }\end{array}$ \\
\hline Use of Visual Aids & $\begin{array}{l}\text { No aids are used or } \\
\text { they are so poorly } \\
\text { prepared that they } \\
\text { disturbed the } \\
\text { presentation. }\end{array}$ & $\begin{array}{l}\text { Aids are difficult to } \\
\text { read. Poor images or } \\
\text { inappropriate } \\
\text { animations. }\end{array}$ & $\begin{array}{l}\text { Aids are marginal. } \\
\text { Font is large enough to } \\
\text { read. Some distracting } \\
\text { backgrounds. }\end{array}$ & $\begin{array}{l}\text { Aids are reasonably } \\
\text { good. Graphics and } \\
\text { animation usage are } \\
\text { appropriate. }\end{array}$ & $\begin{array}{l}\text { Aids presented are } \\
\text { professional and } \\
\text { polished. Font is large } \\
\text { enough. Images are } \\
\text { relevant and help } \\
\text { address the issue. }\end{array}$ \\
\hline Teamwork & $\begin{array}{l}\text { No clear role defined } \\
\text { and no bonding } \\
\text { between group } \\
\text { members. }\end{array}$ & $\begin{array}{l}\text { Minimal participation } \\
\text { from one or more } \\
\text { members. }\end{array}$ & $\begin{array}{l}\text { All group member } \\
\text { participate but one or } \\
\text { more member } \\
\text { dominant }\end{array}$ & $\begin{array}{l}\text { Almost balanced } \\
\text { participation }\end{array}$ & $\begin{array}{l}\text { Balanced participation. } \\
\text { Clear and appropriate } \\
\text { role allocation. }\end{array}$ \\
\hline
\end{tabular}

(b)

\begin{tabular}{|c|c|c|c|c|c|}
\hline \multirow{2}{*}{ Grading Criteria } & 3 & 6 & 9 & 12 & 15 \\
\hline & Poor & Below Expectation & Meet Expectation & Confident & Advanced \\
\hline $\begin{array}{c}\text { Professional } \\
\text { documentation }\end{array}$ & $\begin{array}{l}\text { Binder is poorly } \\
\text { prepared; no efforts in } \\
\text { professional } \\
\text { documentation }\end{array}$ & $\begin{array}{l}\text { Some efforts in } \\
\text { professional } \\
\text { documentation; } \\
\text { substandard physical } \\
\text { binder appearance }\end{array}$ & $\begin{array}{l}\text { Satisfactory } \\
\text { professional } \\
\text { documentation; } \\
\text { acceptable binder } \\
\text { physical appearance }\end{array}$ & $\begin{array}{l}\text { Good professional } \\
\text { documentation; good } \\
\text { binder physical } \\
\text { appearance }\end{array}$ & $\begin{array}{l}\text { Excellent professional } \\
\text { documentation; great } \\
\text { binder physical } \\
\text { appearance }\end{array}$ \\
\hline $\begin{array}{l}\text { Contents - } \\
\text { Completion }\end{array}$ & $\begin{array}{l}\text { Binder contains } 50 \% \\
\text { or less of required } \\
\text { project deliverables }\end{array}$ & $\begin{array}{l}\text { Binder contains } \\
51 \% \sim 69 \% \text { of required } \\
\text { project deliverables }\end{array}$ & $\begin{array}{l}\text { Binder contains } \\
70 \% \sim 79 \% \text { of required } \\
\text { project deliverables }\end{array}$ & $\begin{array}{l}\text { Binder contains } \\
80 \% \sim 89 \% \text { of required } \\
\text { project deliverables }\end{array}$ & $\begin{array}{l}\text { Binder contains } \\
90 \% \sim 100 \% \text { of required } \\
\text { project deliverables }\end{array}$ \\
\hline Contents - Accuracy & $\begin{array}{l}\text { Little information is } \\
\text { provided in the } \\
\text { deliverables with poor } \\
\text { accuracy }\end{array}$ & $\begin{array}{l}\text { Some information is } \\
\text { provided in the } \\
\text { deliverables with low } \\
\text { accuracy }\end{array}$ & $\begin{array}{l}\text { Solid information is } \\
\text { provided in the } \\
\text { deliverables with } \\
\text { acceptable accuracy }\end{array}$ & $\begin{array}{l}\text { Great amount of } \\
\text { information is } \\
\text { provided in the } \\
\text { deliverables with good } \\
\text { accuracy }\end{array}$ & $\begin{array}{l}\text { Excellent coverage of } \\
\text { information in the } \\
\text { deliverables with } \\
\text { impeccable accuracy }\end{array}$ \\
\hline Formatting & $\begin{array}{l}\text { No obvious efforts in } \\
\text { compliance with } \\
\text { formatting } \\
\text { requirements }\end{array}$ & $\begin{array}{l}\text { Some efforts in } \\
\text { compliance with } \\
\text { formatting } \\
\text { requirements }\end{array}$ & $\begin{array}{l}\text { Acceptable formatting, } \\
\text { quite a few mistakes } \\
\text { and inconsistencies }\end{array}$ & $\begin{array}{l}\text { Good and consistent } \\
\text { formatting, very few } \\
\text { mistakes }\end{array}$ & $\begin{array}{l}\text { Excellent formatting, } \\
\text { almost impeccable } \\
\text { consistency }\end{array}$ \\
\hline $\begin{array}{l}\text { Organization/ } \\
\text { Collaboration }\end{array}$ & $\begin{array}{l}\text { No obvious efforts in } \\
\text { logical organization of } \\
\text { manual; no group } \\
\text { collaboration }\end{array}$ & $\begin{array}{l}\text { Poor organization of } \\
\text { manual and little sign } \\
\text { of group collaboration }\end{array}$ & $\begin{array}{l}\text { Acceptable manual } \\
\text { organization and group } \\
\text { collaboration }\end{array}$ & $\begin{array}{l}\text { Good manual } \\
\text { organization and } \\
\text { apparent group } \\
\text { collaboration }\end{array}$ & $\begin{array}{l}\text { Excellent manual } \\
\text { organization and } \\
\text { highly consistent group } \\
\text { collaboration }\end{array}$ \\
\hline
\end{tabular}

Figure 4. Grading rubrics for (a) Team Presentation and (b) Team Final Report. 
(a)

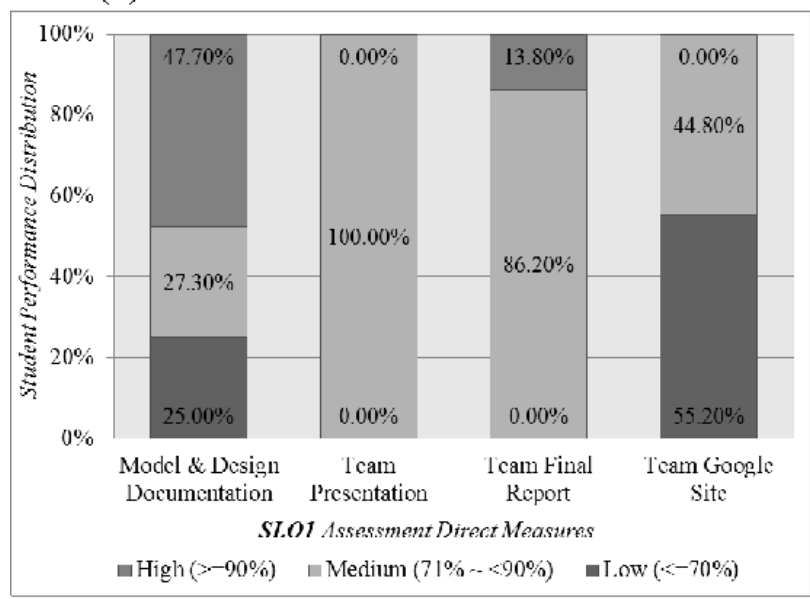

(c)

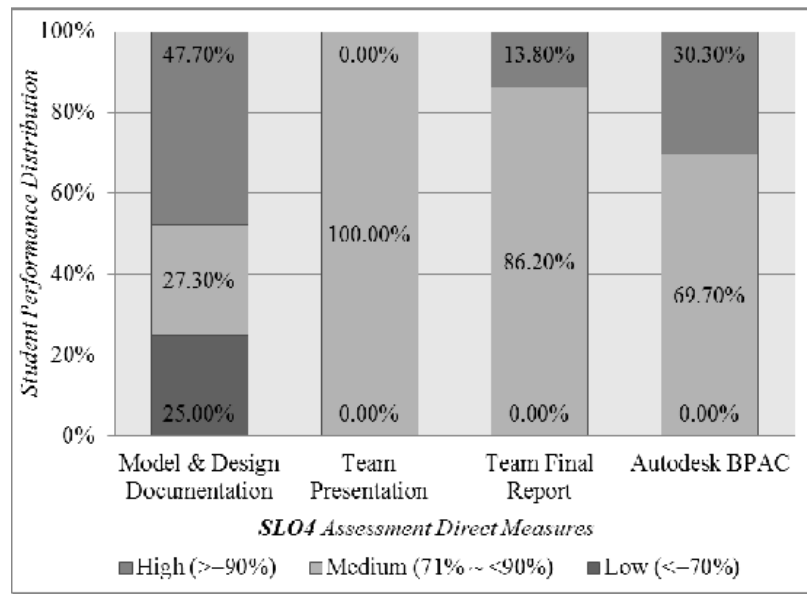

(b)

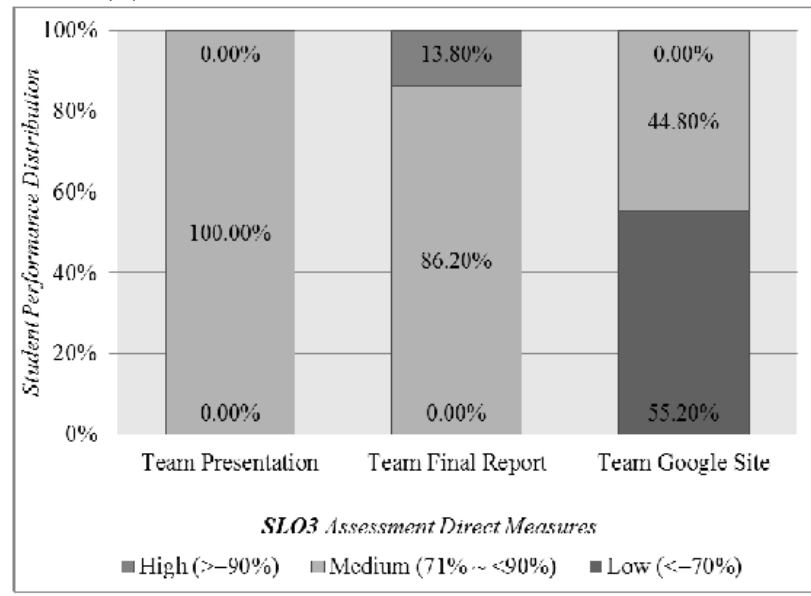

(d)

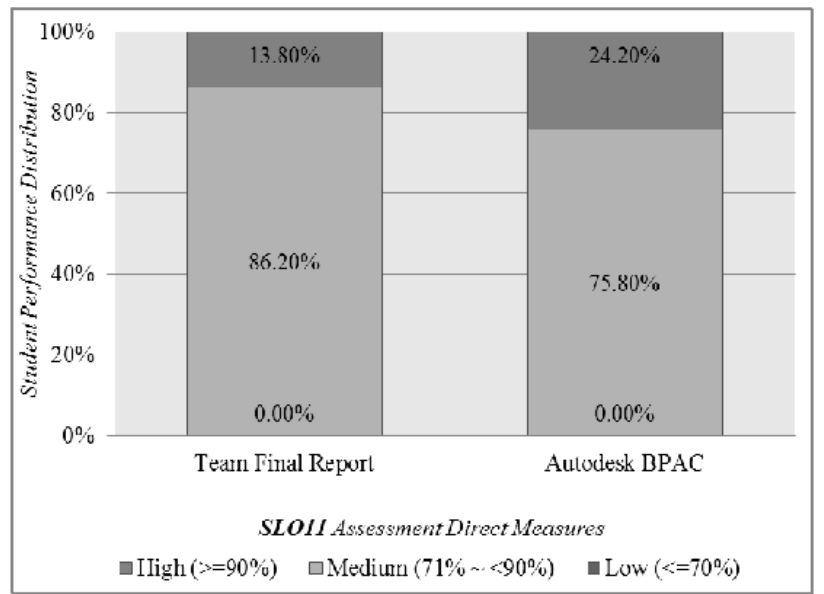

Figure 5. Assessment results with student performance distributions of direct measures for: (a) SLO 1: Communication; (b) SLO 3: Teamwork and Team Relations; (c) SLO 4: Problemsolving and Critical Thinking; and (d) SLO 11: Sustainability.

Instructors used both Entry and Exit surveys as indirect measures in this joint course project. Surveys, providing their subjectivity or even biases, remain as great means to understand students' attitudes and reflection on the project-based learning experience. The Entry Survey was relatively simplistic and aimed at a quick grasp of students' background. Therefore, the analysis was focused on the Exit Survey that was conducted online with institutional Qualtrics service. Out of 29 students from the two classes, 24 completed the survey. The survey had both quiz-like multiple-choice questions as well as open-ended discussions. The goal was to qualitatively evaluate students' perception towards BIM implementation in the sustainability domain, and their confidence in leveraging the knowledge and skills attained from this project to deal with common issues encountered in real world project delivery. A quick example is illustrated in Figure 6, which indicates that the joint course project had a significant positive impact on students' understanding of fundamental concepts of BIM and green building. The Exit Survey also used Likert scales ( 1 to 5 where 5 denotes best performance) to evaluate team performance against several typical team effectiveness indicators, in comparison with a parallel self- 
evaluation. The results are presented in Table 3. It is very consistent across all performance indicators that on average, students rated themselves higher than the rest of the team. The instructors also reflected on individual interviews with project teams through the joint course project, and found out that when conflicts arising, students often attributed the defaults to their peer team members instead of taking the responsibility and making efforts to improve the tem performance. It seemed that there was a lack of leadership among the students, which was concerning the instructors since it was essential to the students' professional career.

(a)

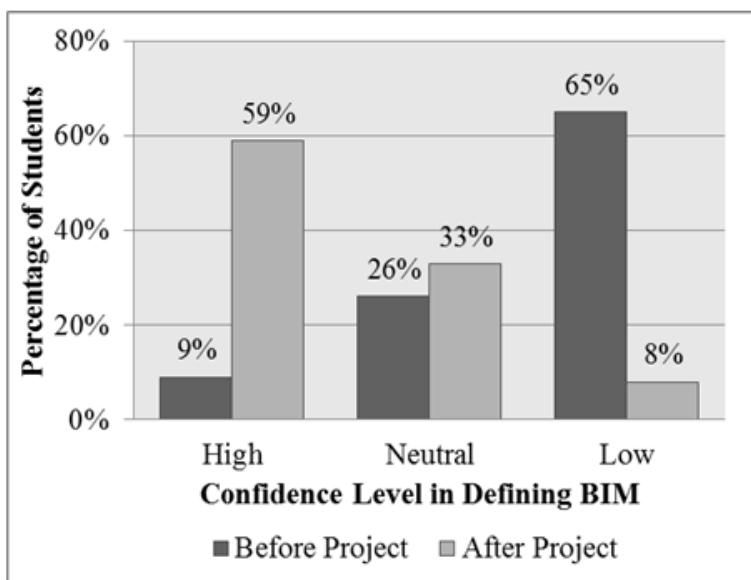

(b)

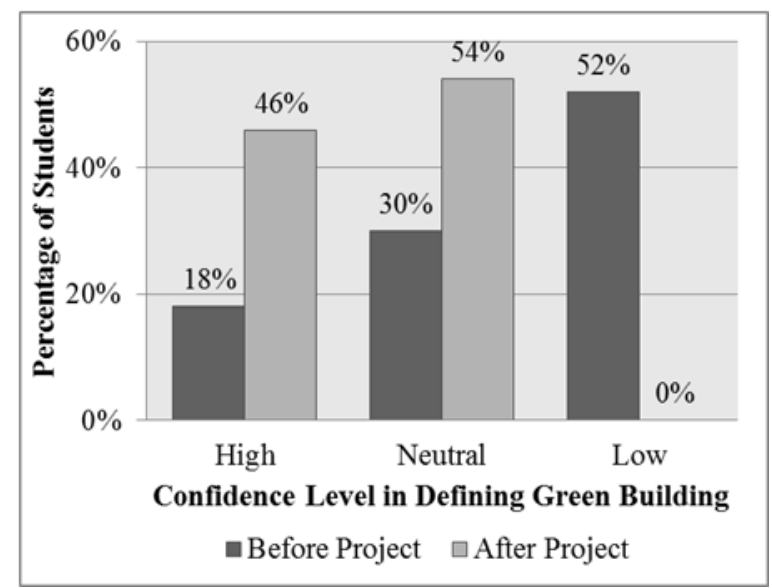

Figure 6. Student confidence in defining (a) BIM and (b) green building before and after joint course project.

Table 3. Evaluation of team project performance: self vs. rest of the team.

\begin{tabular}{lcc}
\hline Project performance indicators & $\begin{array}{c}\text { Survey results in mean Likert scales (1-5) } \\
\text { The rest of the team }\end{array}$ & Self \\
\hline Planning \& Execution & 3.46 & 3.52 \\
Effectiveness & 3.67 & 3.83 \\
Time Commitment \& Contribution & 3.67 & 4.04 \\
Collaboration \& Communication & 3.54 & 3.83 \\
Overall Accomplishment & 3.58 & 3.74 \\
\hline
\end{tabular}

The last part of the survey requested the students to identify both successes and failures of the joint course project, and offer constructive feedback on potential improvement. The most commonly cited success was the fact that they were able to complete the project on time with satisfactory quality, considering the majority of them had never used any BIM applications. They also acknowledged that project-based learning was able to uncover issues that were atypical in conventional lectures and enhanced their working knowledge of BIM in green building projects. The biggest failure as they consistently pointed out was the asynchronous class periods of the two courses, which as they claimed, was "the biggest inconvenience" that undermined their overall learning experience. The students also expressed frustration with constant technological cumbersomeness due to the outdated computers and persisting glitches of the Autodesk Energy Analysis plug-in.

The instructors agreed with students on the technological issues, but a major challenge perceived was the lack of self-motivation among students. They are seldom willing to get out of their 
comfort zone and learn something new. Significant efforts had to be made to keep the students motivated, yet there were constant complaints and negotiations taking place throughout the joint course project. Bringing external speakers from the industry and conducting field trips seemed to help promote the morale. In regard to technical difficulties, the instructors are considering new products such as the Autodesk Revit Credit Manager for LEED for future projects. As for the future scope of work on LEED documentation, due to time constraints, the instructors plan to have students focus on only selected LEED credits rather than completing a full LEED documentation for the project during one semester. Funding is also being sought after for hardware upgrades to create a workplace that facilitates real collaboration in project-based learning.

\section{Conclusion}

Construction and engineering education is facing dual challenges in meeting its academic goals as specified by accreditation and assessment requirements, as well as its professional mission of cultivating competent future workforce for the industry. This paper investigated an emerging trend of integrated BIM and sustainability practices, and aligned it with program assessment efforts in improving core SLOs. Using the project-based learning pedagogy, a joint course project was conducted to experiment innovative strategies to develop student competencies in synergistic implementation of BIM and sustainability. Assessment results indicated solid performance in targeted SLOs, but also revealed weakness that needed improvement. The lessons learned through the joint course project are valuable reference for future endeavors. Results of this study are also expected to be shared with colleagues within the construction engineering education community at Fresno State through course Kaizen workshops.

\section{Acknowledgement}

The authors would like to thank Harris Construction for providing the project documentation and accommodate student field trips.

\section{Bibliography}

${ }^{[1]}$ McGraw-Hill Construction. (2010). Green BIM: How building information modeling is contributing to green design and construction, Bedford, MA.

${ }^{[2]}$ Wu, W. and Issa, R. (2015). "BIM Execution Planning in Green Building Projects: LEED as a Use Case." J. Manage. Eng. 31(1), SPECIAL ISSUE: Information and Communication Technology (ICT) in AEC Organizations: Assessment of Impact on Work Practices, Project Delivery, and Organizational Behavior, A4014007.

${ }^{[3]}$ GSA. (2012). 3D-4D building information modeling, (http://www.gsa.gov/portal/content/105075).

${ }^{[4]}$ DOE. (2011). Commercial reference buildings, Office of Energy Efficiency and Renewable Energy, Washington, DC, (http://www1.eere.energy.gov/buildings/commercial_initiative/reference_buildings.html).

${ }^{[5]}$ Biswas, T., Wang, T. H., and Krishnamurti, R. (2008). "Integrating sustainable building rating systems with building information models." Proc.,13th Int. Conf. on Computer Aided Architectural Design Research in Asia, Association for Computer-Aided Architectural Design Research in Asia (CAADRIA), Hong Kong, $193-200$.

${ }^{[6]} \mathrm{Wu}, \mathrm{W}$., and Issa, R. R. A. (2010). "Application of VDC in LEED projects: Framework and implementation strategy." Proc., CIB W-78 27th Int. Conf. on IT in Construction, International Council for Research and Innovation in Building and Construction (CIB), Rotterdam, Netherlands. 
${ }^{[7]}$ Barnes, S., and Castro-Lacouture, D. (2009). "BIM-enabled integrated optimization tool for LEED decisions." Proc., 2009 Int. Workshop on Computing in Civil Engineering, ASCE, Reston, VA, 258-268.

${ }^{[8]}$ Bank, L. C., McCarthy, M., Thompson, B. P., and Menassa, C. C. (2010). "Integrating BIM with system dynamics as a decision-making framework for sustainable building design and operation." Proc., 1st Int. Conf. on Sustainability Urbanization, Hong Kong Polytechnic Univ., Hong Kong, China.

${ }^{[9]}$ O'Keeffe, S. E., Shiratuddin, M., and Fletcher, D. (2009). "LEED certification review in a virtual environment." Proc., 9th Int. Conf. on Construction Application of Virtual Reality, Univ. of Sydney, NSW, Australia.

${ }^{[10]}$ Azhar, S., Carlton, W., Olsen, D., and Ahmad, I. (2011). "Building information modeling for sustainable design and LEED rating analysis." Autom. Constr., 20(2), 217-224.

${ }^{[11]} \mathrm{Wu}, \mathrm{W}$., and Issa, R. R. A. (2010). "Feasibility of integrating building information modeling and LEED certification process." Proc., Int. Conf. on Computing in Civil and Building Engineering, W. Tizani, ed., Univ. of Nottingham, Nottingham, U.K.

${ }^{[12]} \mathrm{Wu}, \mathrm{W}$. , and Issa, R.R.A. (2014). "BIM Education and Recruiting: Survey-based Comparative Analysis of Issues, Perceptions, and Collaboration Opportunities.” J. Prof. Issues Eng. Educ. Pract., 140(2), 04013014

${ }^{[13]}$ Becerik-Gerber, B., Ku, K., and Jazizadeh, F. (2012). "BIM-enabled virtual and collaborative construction engineering and management.” J. Prof. Issues Eng. Educ. Pract., 138(3), 234-245.

${ }^{[14]}$ Chinowsky, P. S., Brown, H., Szajnman, A., and Realph, A. (2006). "Developing knowledge landscapes through project-based learning." J. Prof. Issues Eng. Educ. Pract., 132(2), 118-124.

${ }^{[15]}$ Bas, G. (2011). "Investigating the effects of project-based learning on students' academic achievement and attitudes toward English lesson." The Online Journal of New Horizons in Education, 1(4), 1-15.

${ }^{[16]}$ Goedert, J. D., Pawloski, R., Rokooeisadabad, S., and Subramaniam, M. (2013). "Project-Oriented Pedagogical Model for Construction Engineering Education Using Cyberinfrastructure Tools.” J. Prof. Issues Eng. Educ. Pract., 139(4), 301-309.

${ }^{[17]}$ Liu, Y., Lou, S., Shih, R., Meng, H., and Lee, C. (2010). "A case study of online project-based learning: The beer king project.” Int. J. Technol. Teach. Learn., 6(1), 43-57.

${ }^{[18]}$ Kubiatko, M., and Vaculová, I. (2011). "Project-based learning: Characteristic and the experiences with application in the science subjects." Energy Educ. Sci. Technol. Part B, 3(1), 65-74.

${ }^{[19]}$ Walters, R. C., and Sirotiak, T. (2011). "Assessing the effect of project based learning on leadership abilities and communication skills." Proc., of 47th ASC Annual Int. Conf., the Associated Schools of Construction. 